\title{
Data digging: Evaluation of Indonesia's built heritage information
}

\author{
R. Wulandari \\ Telkom University, Bandung, Indonesia \\ W.A. Rahmy \\ University of Florida, Florida, USA
}

\begin{abstract}
A monument, a built heritage, needs information and narration to be shared with the public as part of their story that enrich their value as a cultural heritage. Digital technology has given us data and repositories on almost everything. It has made online research easier. This study is an empirical study on how to use and develop data digging for architectural history research on a monument or an object of a built environment using cases studies. From the case studies, it was understood that the information of an object being spread out are mostly incorrect thus need correction. Data digging with keyword research can confirm information of a built heritage, correct the mistaken information, and add other relevant information. Online repositories for Indonesian built heritage are available not only in The Netherlands, but also in other countries, in other languages, which need to be selected and listed.
\end{abstract}

Keywords: information technology, digital repository, built heritage,

\section{INTRODUCTION}

The world of the built environment has a record of its development, particularly a record of a building or a monument, even perhaps a record of the building's landscape and environment, or even a city. This record might be the note on its construction history, its design and planning, its social history that involved events, the research done on it afterwards, trading record, guest book, or even design drawing. All of these records can be found scattered in the building itself, in the contractor office, at the architect's studio, photograph at the owners' property, painting or story by an artist or a traveler, a magazine, a newspaper, even postcard and stamps. The information contained in the records could be very helpful for an architecture historian in understanding a historic monument.

A monument or site, historic monument/site in this case, needs evaluation on its origin, authenticity, integrity, and history to be valued as heritage. The information needed including the time of construction or inauguration, changes happened, original function. The information gained from archives and records can help historian and architectural historian in determining a monument's age, architectural style, changes from its original design, layer of history, layer of physical changes in the building, its landscape, even its surrounding.

Archive and historical data have been used regularly by historians. In the last decade, architecture historians in the Netherlands used archives and historical data to do research on built environment at their former state colony, one of it is Indonesia. Since the rise of digital technology, with its many facets, archives and data have been digitized and put online for public information and research use. This big data of historical archives and records can be accessed freely by anyone around the world.

The Dutch government service, the Cultural Agency, in cooperation with National Archives, university, library, and Dutch architectural historian have been making workshops on digging 4 data to introduce and popularize the rich online repository of the built environment in their former 
state of colony. From the cooperation, a guideline on how to do research on archive base was published (Akihary et al. 2017).

However, is this Dutch archive repository the only one that Indonesian researchers can count on in determining a value of a building, a monument, or even a region? Is there any other repository that can be consulted for research needs? And how to do it? This study is an empirical research with a study case that practiced and searched further use of archive and records repository online as well as trying to seek if there is another repository available to be consulted.

\section{DIGGING 4 DATA}

It is without doubt that the digital world, the digital information and communication technology, the computerized technology have changed our world in general. It has changed the way we seek and process information. It has provided people with big data and endless repository on everything in life, not to mention the heritage world. The digital information and communications technologies (ICT) have produced a wide range of applications for collecting and processing historical data, documenting and monitoring the physical conservation of objects and monuments, visualizing historic structures and environments, and creating interactive information (Brizard \& Derde 2007).

Digging for Data was popularized in Indonesia by a Dutch architectural historian as Digging4Data is a method in researching the built environment in their former state of colony, particularly Indonesia. The data digging has been recently introduced in Indonesia through a workshop in 2014. The workshop was held together by National Archive of Indonesia and the Netherlands, University of Delft, and Cultural Heritage Agency of the Netherlands (RCE) (Akihary et al. 2014). The workshop was followed by several Indonesian universities and heritage communities. However, the method is still less understood and only few were starting using it.

The digging for data method uses repositories online and offline from books, archives, records, photographs, maps (Pauline \& van Roosmalen 2014). The offline repositories are available in the library of government services, universities, books. In the meanwhile, the online repositories are available the internet. However, not all the information from the internet can be taken for granted as a valid source.

Akihary (2014) listed several valid and selected repositories from Indonesia and the Netherlands, containing text documents, photographs, films, maps, archives, magazines, and newspapers. These repositories are to be consulted for research on Indonesia's built environment (colonial architecture and town planning) from 1620-1950. The selected repositories are Arsip Nasional Republik Indonesia (ANRI); Atlas of Mutual Heritage VOC and WIC documents; Koninklijke Bibliotheek (KB, National Library); Delpher; Koninklijk Instituut voor de Tropen; Leiden University Libraries; Koninklijk Instituut voor Taal-, Land- en Volkenkunde (KILTV, Royal Netherlands Institute of Southeast Asian and Caribbean Studies); Nationaal Archief (National Archive); Het Nieuwe Instituut Nederlands (former Architectuur Instituut, NAi); Stichting Bibliografieën en Oeuvrelijsten van Nederlandse Architecten en Stedenbouwkundigen (BONAS); Perpustakaan Nasional Republik Indonesia (PNRI); Pusat Dokumentasi Arsitektur; Nationaal Museum van Wereldculturen (NMVW); Rijksmuseum Volkenkunde (Collection \& Library); Rijksmuseum Tropenmuseum; Universitaire Bibliotheken Leiden; KITLV Collection; University of Technology, Delft Repository on European colonial architecture c.1850-1970; Towards A New Asian Partnership (TANAP) or portal for Dutch East India Company Archives and Research. Most of the information in the archives, offline or online, are available in Dutch and Indonesian. This gives limitation to user or researcher needing information since Indonesia researcher do not speak Dutch unless they are historian who studied Dutch.

\section{METHOD}

This study was an empiric study using data digging with study cases as method. Data digging was used as a method in testing and researching for correct information of a building from the 
colonial era in Indonesia. Public buildings and plantation site have been chosen as object of study. Public buildings were chosen because they are visible and recognizable by public, located in the city center, is listed, and acknowledged by public as a heritage property. Meanwhile, plantation site was also chosen as non-building study case because this site was created by the Dutch during colonial era.

The empiric study was done through keyword search of the chosen buildings and site in several languages. Languages used for keyword searching were Dutch, Indonesian, English, French, and Spanish. Several languages were used to find out if there is other information or repositories available online in other language than Indonesian and Dutch. Asian languages were not used due to author's incapacity in Asian languages other than Malay. As for keywords used, name of buildings or site were primary keyword, followed by buildings' function, name of region, name of the buildings' architect where available.

Information found in the online repositories were then compared to existing information already provided by local government or local communities. Different information was crosschecked to ensure validity of the data as well as the source of the information whether the source is reliable.

\section{RESULT AND DISCUSSION}

\subsection{Result}

The first chosen public building for the study was Gedung Gas Negara (PGN) Bandung located at Braga Street in Bandung. It was chosen because of its location in the city center, its visibility to public, and the visibility of its information to public. The building was designated as the city cultural heritage protected by local law and classified as "A" class heritage which means no physical changes can be made to the building. For the need of public information and socialization of the law as well as the building statutes, a placate was put by the government on the building façade. The marble placate gives information on the building's name, time of construction or inauguration, name of the architect, the building's function and other added information, and the name of the law protecting the building.

On the marble placate on Gedung Gas Negara's façade, it was said that the building was built in 1930 by an architect named R.L.A. Schoemaker and that it was functioned as gas factory. A question was raised on the information about the building's former function as a gas factory. The question was raised because the typology of the building is an office typology with divided rooms and a meeting hall. There is no storage or production facility present in the building. Thus, information saying that it functioned as a factory needed to be crosschecked and confirmed.

A data digging was done to confirm the mentioned question. First data digging was through book repository. A book written by C.V. van Dulleman and a book written by Huib Akihary became the two first repositories. From van Dulleman's book, it was understood that the building was built in 1919 , and not 1930. It was also found in the first book that it was designed by the architect C.P. Wolff Schoemaker. In the meanwhile, no information of the building was found from the second book.

Next, data digging was done through the internet using keywords that would match the building. Keywords used were former name of the building, former name of the gas company, the street address. The keyword came out from following website https://www.indischeliterairewandelingen. $\mathrm{nl} /$. On the website, little information in Dutch was saying that the building was built in 1919 by architect C.P. Wolff Schoemaker. The web also mentioned that the building was used as a central office for the gas company. Information from this website confirmed the one from van Dulleman's book and counter every information written in the placate installed on the building's façade. Thus, most of the information written on the marble placate on the façade are incorrect. Other information using keywords from other languages were not found for this building.

The data digging method was also used to test the availability of information on another public building and site. The second chosen study case for building was religious buildings, in this case the Indonesian mosques. For the Indonesian mosques, keywords used were name of the mosques, words "Indonesian mosques", region name. For the second study case, information searched were 


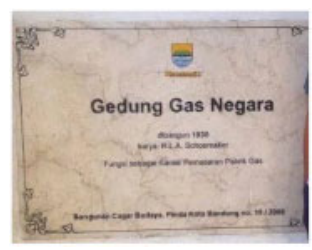

Figure 1. Information about Gedung Gas Negara provided by the city, Paguyuban Pelestarian Budaya Bandung.

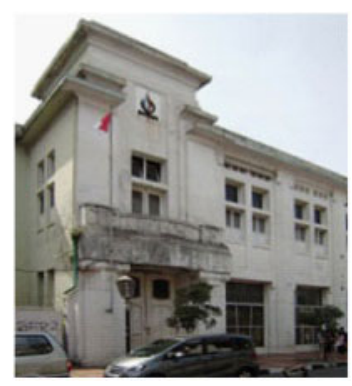

Figure 2. Gedung Gas Negara (PGN) Bandung, (Source: https://www.indischeliterairewandelingen.nl/)

those related to construction date, the builder (not architect), physical form, and shape. Surprisingly, information on Indonesian mosques can also be found in French repositories, mostly as research publication results. Several repositories that provided information on Indonesian mosques are: https://www.persee.fr/; https://www.gutenberg.org/; https://revue-archipel.fr/index_en.html; and https://brill.com/view/journals/bki/2/1/article-p384_20.xml

The data digging was also tested to get information about site (landscape) with plantation site as the case. Keywords used for plantation case was name of the plantation, former name of the plantation, name of the plant, region name, company name, name of former owner. Beside the previously mentioned repositories, information concerning plantation company was also found in Google books repository, and in legal document available in the google books library.

Data digging used for Indonesian mosques and plantation site provided information related to their history, form, year of construction, and people involved in the construction or development of the object. Every gathered information from data digging helped confirm the validity and accuracy of existing information known by local citizen, government, public in general, also researcher and academician.

\subsection{Discussion}

In Bandung, there are 100 buildings that are recognized as heritage by the local heritage law. Each of the building is marked with a marble placate containing information of each building. However, the information contained might not be valid or not $100 \%$ correct.

From the case of Gedung Gas Negara, it was confirmed that information written locally, been red by citizens, is not a valid information. Material written loud and clear on the building's façade turned out to be almost completely wrong. Only information about the law protecting it is correct. In the meanwhile, this information is being read by every passerby, every citizen, and every visitors of the building. Unless the information is corrected, the missing information is spread out and would be considered as fact by those who read it.

There are factors that could cause the misinformation of a monument. Several possibilities that could occur are the government has no valid source when making the information, the source used was considered credible but was not crosschecked or confirmed, the information searched 
was using limited available source, or taking for granted the already known information without further research. For whatever the condition, confirming information on a monument is necessary, especially when the monument is designated as heritage property. Valid historical information must be provided to support the designation and to support the value of the monument.

Digging for data in this case must be done prior to a monument's designation as a heritage property to evaluate its value. It should also be done to confirm every information already known by public. Validity of every information concerning a building, or a site must be ensured prior to public awareness publicity. Valid and accurate historical information of a heritage property is a capital for the object's narration to public.

From the case of Indonesian mosques and plantation site data digging, it was found that creativity in creating keywords related to the object is a fundamental skill. Foreign language skill of a researcher would be beneficial in digging for data activity. A researcher who wishes to do digging for data of Indonesia's built heritage needs to understand Dutch and several other European and perhaps Asian languages. However, with the aid of technology and online tools, the online translation services could do a little help on such research especially in creating keywords. Researching keywords in another language helps researchers in finding out if there are other repositories from other countries outside Indonesia and the Netherlands having some information on the built heritage researched. This is true for the case of mosque where French repositories were found to have some resources on it.

Some information concerning landscape and social situation can also be found on Project Gutenberg as information written in books related to the keyword researched. Other online repositories that could be useful as well are universities dissertation repositories. Some universities provided their students' dissertation online. Along with other repositories, Google books was also found to contain some information on the searched object or at the least, something related to searched object. By all means, in accordance with Akihary et al.(2014), selected Dutch repositories are primary source for the Indonesian colonial heritage data.

\section{CONCLUSION}

Historical data research is needed to confirm information of every historical object. Not every present existing data is valid and accurate. It is necessary to find out detailed information from offline and online repositories to confirm historical information of a built heritage to avoid informational mistakes.

Repositories are available not only in The Netherlands, but also in other countries in other languages. Consulting repositories in other countries using other languages will help enrich historical information of a colonial heritage property. Thus, it is important for a researcher to train their ability in keyword researching of an object of their study. The keyword research would be beneficial for the researcher to find more information not only from the listed sources, but also from other possible sources. Online repositories itself need to be selected, the information inside needs to be checked and rechecked to get a valid accurate historical data on an object of built heritage.

Capability in using online repositories, if offline is difficult to access, is important in research of historical built heritage. When the built heritage is related to history of colonialism, then there are more repositories to be consulted from both countries - ex-colonizer and ex-colony. All these repositories can be used to find information on landscape, city history, urban planning. Online repositories are free and open access, but one must be cautious in choosing a valid repository. A list of trusted sources should be made and updated to make digging for data more efficient and effective.

\section{REFERENCES}

Huib Akihary et al., 2014. Collecting and Connecting Historical Data for Inner City Development in Indonesia. Workshop Report Jakarta, Indonesia, October 27-28. 
Huib Akihary, Nadia Purwestri, and Pauline K.M. van Roosmalen. 2017. Digging4Data How to do research on the built environment in Indonesia, 1620-1950. Jakarta, The Hague, Amersfoort.

Brizard, Tamara and Willem Derde. 2007. Basic Guidelines for Cultural Heritage Professionals in the Use of Information Technologies. How Can ICT Support Cultural Heritage. http://media. digitalheritage.se/2010/07/Basic_Guidelines_TII.pdf.

Pauline K.M. van Roosmalen. 2014. A repository for sources about European colonial architecture and town planning (c.1850-1970): Creating a digital (research) tool. Workshop Historical Data for Inner City Development Jakarta. October 27-28.

Pauline K.M. van Roosmalen. 2014. Patience \& Perseverance: How to go about historical research Workshop Historical Data for Inner City Development Jakarta October 27-28. 